\title{
Prevalence of Intimate Partner Violence and Associated Factors among ART user's Women Attending Adama Town Public Health Facility, Central Ethiopia 2019
}

\section{Girma Garedew Goyomsa}

College of health Science Selale University

\section{Aderajew Niguse Teklehaymanot}

Jimma University College of Public Health and Medical Sciences

\section{Teklu Arga}

Jimma university college of public health and medical Science

Leul Deribe ( $\nabla$ leul.deribe@gmail.com )

Addis Ababa University https://orcid.org/0000-0003-3379-3046

Research

Keywords: Intimate partner violence, Antiretroviral treatment, HIV/AIDS

Posted Date: November 4th, 2020

DOl: https://doi.org/10.21203/rs.3.rs-99727/v1

License: (c) (1) This work is licensed under a Creative Commons Attribution 4.0 International License.

Read Full License 


\section{Abstract}

Background: The aim of this study was to determine prevalence and associated factors of intimate partner violence (IPV) among antiretro varial therapy (ART) user women visiting chronic care unit, Adama town public health facility, Ethiopia.

Methods: A facility-based cross-sectional study was conducted from March 1- April 1, 2019 among 396 ART user women. Validated WHO tools were used to measure IPVAW and systematic random sampling technique was used to select individuals. The collected data were entered, using Epi data 4.4.1 and analyzed using SPSS version 24. Descriptive statistics were used to compute summary statistics and proportion. Multivariable logistic-regression were used to identify predictors of IPV.

Result: A total of 396 women participated in the study. The prevalence of current IPV was $32.3 \%$ and lifetime IPV was $45.5 \%$. Having history of first coerced sexual intercourse [AOR $=3.0(1.73,5.44)]$, partner engagement in multiple sexual relationships $[A O R=2.2(1.21,4.06)]$, justifing wife beating is normal when she refused to have sex with her husband [AOR $=2.3(1.29,4.12)]$, using contraceptive [AOR = 3.33 $(1.67,6.62)]$ and women whose partner were farmer $[A O R=3.9(1.43,10.79)]$ were found to be significant predictors of IPV among sero-positive women

Conclusion: One in three women reported at least two or more forms of violence from their partner. Individual level factor (exposure to first coerced sex, partner's occupation, contraceptive use and women's acceptance of violence) and relationship factor (male multi-partnership) were identified as a predisposing factor. In view of this addressing risky behavior practiced among male partner and challenging women attitude toward violence was crucial in reducing violence.

\section{Plain English Summery}

Intimate partner violence against women (IPVAW) is a gross violation of human rights within an intimate relationship that causes physical, sexual or psychological harm to the victim. HIV infected women face increased risk of IPVAW. However, the level to which they experienced violence has not been well investigated in the local context. In this study HIV positive women attending ART clinic at public health facility at Adama city administration, Ethiopia were asked about their experience of intimte partner violence. We implemented facility based cross sectional study among 396 ART user women from March 1- April 1, 2019. The study used intervewer adminstraded quastuinniere adoted from cross-culturally validated questionnaires developed by the WHO. The study participants were selected using systematic simple sampling.

In this study around one in three women of HIV positive women experianced IPV within the last twelve months and $45.5 \%$ experianced lifetime IPV. HIV positive women who had history of first coerced sexual intercourse, partner engagement in multiple sexual relationships, justification for wife beating is normal when she refused to have sex with her husband, used contraceptive, and had farmer partner reported 
higher rate of IPV. Therefore, in addition to make combined effert by different stakeholders to address risky behavioures of male partners, it is important to challenging womens' attitude toward violence.

\section{Introduction}

The problem of violence against women is considered as an iceberg phenomenon since it is underestimated and undisclosed especially among sero-positive women. United Nations Declaration on the Elimination of Violence against Women (UNDVAW) affirm that violence against women (VAW) constitutes a violation of the rights and fundamental freedoms of women and impairs their enjoyment of those rights and freedoms (1). Intimate partner violence against women (IPVAW) is defined as a behavior within an intimate relationship that result in or likely to result in physical, sexual or emotional harm to individual (2). IPVAW refers specifically to abuse within an intimate relationship while VAW is broader and encompasses any abuse perpetrated within a family or outside the family (3). The occurrence of each forms of IPVAW are often characterized by their coexisting nature i.e. physical IPVAW is often followed by sexual, and is usually accompanied by psychological violence (4).

Now a day IPVAW and HIV infection are extensively interconnected, i.e. one exacerbates the burden of the others. Intimate partner violence increase the risk of HIV acquisition and being living and diagnosing with HIV/AIDS is also related with increased occurrence of new or worsening of existing $\operatorname{IPVAW}(5,6)$. As a result of this it is accepted as a root cause that predispose women for HIV infection and remains parts of their life after they are tested positive $(7,8)$. This consequence makes large number of women living with HIV regularly face stigma, discrimination and violence at a greater severity, making them to lead poorer quality of life than their counterpart $(9,10)$.

Globally around $35 \%$ women experiences violence, out of which $30 \%$ of violence are perpetrated by partner, making intimate partner violence the commonest form of all violence against women (5). Higher rates are seen among HIV-infected populations, and world health organization estimates, women who are sero-positive have 1.52 greater odds of experiencing IPV compared to women who are not seropositive(11). By region the prevalence intimate partner violence among sero positive women in Africa is among the highest. It ranges from $5 \%$ in south African to $37 \%$ in the democratic republic of Congo(12). In Ethiopia, the past 12 month partner violence among reproductive age women were $20 \%$, with some study reporting up to $46 \%(12,13)$.

The effect of intimate partner violence among sero-positive was found to be multidimensional that it affects both partners by increasing the risk of future ill health. Fear of new or increased violence prevents women from disclosing her sero status to partner, which may lead to unprotected sex and an increased risk of HIV/STI transmission to her partner $(14,15)$. On the other hand it affect women wellbeing and deteriorates women skills required to make independent decisions about sexual health (16). This in turn lead the women to have low relationship power, and impaired communication on issues regarding negotiation of condom and safe sexual practice which may increase women chance of re infection with a new virus and develop viral resistance (6). 
Beyond re-infection with new virus, it acts as a barrier that prevents women enrollment into care continuum i.e. (linkage into care, retention in care, adherence to drug and viral suppression $(17,18)$. As a result many HIV positive women remain out of care and fail to take up treatment or non-adherent to ART with a meta-analysis of this evidence suggesting of $55 \%$ lower odds of self-reported ART adherence (19, 20). A consequence of reduced adherence to HIV care and treatment predispose women to greater risk of virologic failure (36\% decreased odds of viral suppression), lower CD4 count, higher incidence of opportunistic infection, decrease prevention of mother to child trasnsmission (increase infant morbidities) and greater risk of her own death $(18,21-23)$.

Due to this complex interactions of violence and HIV infection United nation general assembly recognized IPV as major threat for the achievement of 2030 goal of ending HIV epidemic through prevention of three ninety achievement by 2020 G.C (24-26). As a result of this HIV prevention program at national and international level has focused on the importance of stopping VAW as a strategy in controlling HIV epidemics as it increased risk of HIV infection and exacerbated in HIV positive women $(24,27)$. To respond effectively toward controlling effort it requires adequate information regarding prevalence, form of violence and predicting factors. However, only little is known regarding experience and predicting factors as much study focuses on women of general population and lifetime violence experience which may not predict true figure of violence after the women become sero-positive. Therefore, the study aims to fill the gap by providing important information on the prevalence and the reason behind current IPV experience among ART users' women.

\section{Method}

\section{Study Area and Period}

Adaama town (population 220,212) is located in Oromia regional state of Ethiopia, $99 \mathrm{~km}$ southeast of, the capital city, Addis Ababa. The town has one government hospital and three health center that provides ART services for about 10,944 sero-positive individuals (4517 male and 6427 female) age greater than 15 years. Four thousand seventy two ART user's women were currently served in hospital while 2345 of women were served in health center. The study was conducted from March 1-April 120

\section{Study design and procedure}

Facility based cross sectional study design was employed. All women aged 15 years and above who were using ART services in Adama town public health facility providing ART service were taken as a source population. The required sample size was determined by using single population proportion formula with the assumptions of $46 \%$ proportion of IPV among sero- positive women $(P)$ taken from study conducted in Ethiopia (13), 95\% confidence interval and 0.05 marginal errors. After imploying correction formula and addind $10 \%$ non response rate, final sample size was found to be 396 . 
All public health facilities with ART service i.e. one hospital and three health centers were included in the study. Individual are selected systematically (every third) from each facility after conducting proportion to size ratio allocation of a total sample size based on average client served in each health facility.

\section{Measures}

Variable of interest was a report of current intimate partner violence and assessed by using structured, interview administered questionnaire. The questionnaire was initially designed in English and translated into Amharic language by the translator, and then translated back to English by a third person to check for consistency. Cross-culturally validated questionnaires developed by the WHO (2005) for research on intimate partner violence were used to measure current intimate partner violence (28). Sexual violence measured using three items (being physically forced to have sexual intercourse against her will from her partner, having sex because she was afraid of what her husband might do and being forced to do something sexual that she found humiliating or degrading), six items for physical (slapped or thrown something at her, pushed/shoved her, hit with fist/thrown something that could hurt, choked/burnt her on purpose, threatened her with/actually used a gun and kicked/beaten up) and four items (insulting, Belittling or humiliating, scaring and threatening to hurt) for emotional violence was used. Having answered "yes" to at least one item in physical and/or sexual violence was categorized as women faced intimate partner violence.

Perceived Social support was measured using 12-item multidimensional Likert scale. The total sums of score range from 12 to 84 and reliability is between 0.89 and 0.91 by Cronbach's (29). Alcohol use for respondent was measured using alcohol use disorder identification test (AUDIT-C), which comprises three questions, each scored from $0-4$, for a total summed score of $0-12$. A score of 3 or higher indicates hazardous drinking for women (dichotomized)(30).

Data collection process was supervised by two BSc, nurses who have experience in supervision and four female deploma nurses collected data. The data collection process was taken place in a private room during client exit from ART unit.

\section{Data analysis}

After data collection, each questionnaire was checked for completeness and consistence of the information obtained from the respondent. Then data was entered into epidata manager version 4.4.1 to minimize errors and designing of skipping pattern. Then data were exported to SPSS version 24 for cleaning, editing and analysis. The data were checked for missed values and outliers. To answer the second objective, chi-square assumption was checked before performing bivariate analysis. Then all variables having $p$-value of $\leq 0.25$ and variable deemed to be important were considered as a candidate for multivariable logistic regression models. Multivariable logistic regression at the $95 \%$ confidence level was used to identify the predictors. A significance level of 0.05 was taken as a cutoff value for all statistical significance tests.

\section{Results}


A total of three hundred ninety-six (396) ART users' women, age greater than 15 year were enrolled into the study providing full response rate.

\section{Study population characteristics}

Nearly half, 190 (48\%) of the respondent were in the age range of 25-34 year with the mean age of 33.37 years $((S D)=7.065 y r s)$. Oromo was the predominant ethnic group, $217(54.8 \%)$ and $226(57.1 \%)$ of the respondent were orthodox Christian followers. The mean duration of the relationship of the partners were 10.06 years $(S D=6.54 y r s)$ and more than half $226(57.1 \%)$ were in a marital union. Some of the socio-demographic of both partners were summarized in (Table 1 ). 
Table 1

Socio-demographic characteristics of ART users women attending Adama town public health facility, Central Ethiopia, $2019(\mathrm{n}=396)$

\begin{tabular}{|c|c|c|}
\hline Socio-demographic characteristics & Frequency $(\mathrm{N}=396)$ & Percentage (\%) \\
\hline \multicolumn{3}{|l|}{ Age } \\
\hline $15-24$ & 39 & 9.9 \\
\hline $25-34$ & 190 & 48.0 \\
\hline $35-44$ & 136 & 34.3 \\
\hline$\geq 45$ & 31 & 7.8 \\
\hline \multicolumn{3}{|l|}{ Religion } \\
\hline Orthodox & 226 & 57.1 \\
\hline Muslim & 81 & 20.4 \\
\hline Protestant & 57 & 14.4 \\
\hline Other* & 32 & 8.1 \\
\hline \multicolumn{3}{|l|}{ Ethnicity } \\
\hline Oromo & 217 & 54.8 \\
\hline Amhara & 104 & 26.3 \\
\hline Gurage & 40 & 10.1 \\
\hline Other** & 35 & 8.9 \\
\hline \multicolumn{3}{|l|}{ Marital Status } \\
\hline Married & 226 & 57.1 \\
\hline Cohabiting & 85 & 21.5 \\
\hline Regular partner \& living apart & 66 & 16.7 \\
\hline Divorced & 19 & 4.8 \\
\hline \multicolumn{3}{|l|}{ Respondent Educational Level } \\
\hline No education & 181 & 45.7 \\
\hline Primary & 125 & 31.6 \\
\hline Secondary & 69 & 17.4 \\
\hline
\end{tabular}

Other * catholic

Other** Tigre, Wakefata religion, Adare \& Hamer ethnicity, Gov't (Government) 


\begin{tabular}{|c|c|c|}
\hline Socio-demographic characteristics & Frequency $(\mathrm{N}=396)$ & Percentage (\%) \\
\hline Tertiary \& above & 21 & 5.3 \\
\hline \multicolumn{3}{|l|}{ Occupation of respondent } \\
\hline Gov't employees & 56 & 14.1 \\
\hline Merchant & 99 & 25.0 \\
\hline Day laborer & 95 & 24.0 \\
\hline Farmer & 30 & 7.6 \\
\hline Housewife & 116 & 29.3 \\
\hline \multicolumn{3}{|l|}{ Partner-educational Level } \\
\hline No formal Education & 85 & 21.5 \\
\hline Primary & 131 & 33.1 \\
\hline Secondary & 111 & 28.0 \\
\hline Tertiary \& above & 69 & 17.4 \\
\hline \multicolumn{3}{|l|}{ Partner occupational status } \\
\hline Unemployed & 125 & 31.6 \\
\hline Farmer & 46 & 11.6 \\
\hline Merchant & 89 & 22.5 \\
\hline Gov't employees & 139 & 34.3 \\
\hline \multicolumn{3}{|l|}{ Dowry/ bride price paid } \\
\hline Yes & 139 & 56.7 \\
\hline No & 106 & 43.3 \\
\hline \multicolumn{3}{|c|}{ Level of income compared to her partner } \\
\hline More than partner & 58 & 14.6 \\
\hline About the same & 89 & 22.5 \\
\hline Less than partner & 249 & 62.9 \\
\hline \multicolumn{3}{|l|}{ Other * catholic } \\
\hline \multicolumn{3}{|c|}{ Other ${ }^{\star \star}$ Tigre, Wakefata religion, Adare \& Hamer ethnicity, Gov't (Government) } \\
\hline
\end{tabular}


Information on some behavior from both sides had also been asked. Accordingly about 203 (51.3\%) of the women had reported that their current or most recent partner had currently involved in multiple sexual relation with another woman. Concerning their own number of regular partner around 84 (21.2\%) women reported that they have more than one partner. (Table 2).

Table 2

Behavioral characteristic among ART users' women attending Adama town public health facility, Central Ethiopia, $2019(n=396)$

\begin{tabular}{|lll|}
\hline Behavioral characteristic & Frequency (n) & Percentage (\%) \\
\hline Number of partner for women & & \\
\hline Only one & 312 & 78.8 \\
\hline More than one & 84 & 21.2 \\
\hline Male partner hx of multiple sexual relation & & \\
\hline Yes & 203 & 51.3 \\
\hline No & 193 & 48.7 \\
\hline Respondent alcohol use history & & \\
\hline Hazardous use & 79 & 19.9 \\
\hline Non-hazardous use & 317 & 80.1 \\
\hline Partner alcohol use history & & \\
\hline Everyday & 143 & 36.1 \\
\hline $1-2$ times a week & 67 & 16.9 \\
\hline $1-2$ times a month & 32 & 8.1 \\
\hline Never & 183 & 38.9 \\
\hline Past 12 month Partner involvement in fight & & 38.4 \\
\hline Yes & 152 & 61.6 \\
\hline No & 244 & \\
\hline Respondent Sero-status disclosure to partner & & \\
\hline Yes & 28.1 \\
\hline No & & \\
\hline Values are presented as frequency and percent & & \\
\hline
\end{tabular}

\section{Reproductive and General Health related characteristic of the women}


About 126 (31.8\%) of respondent had started a sexual act before fifteen years of age with the mean age of 16.36 years $(S D=2.744)$ from which around $152(38.4 \%)$ of the women starts their first sexual act without their interest. The respondents had known they were HIV positive for a period ranging from 117 years with a mean age of 7.75 years $(S D=3.66 y r s$. The average length of time since ART initiation were 7.3yrs (SD $=3.617)$ and one hundred one $(25.5 \%)$ of respondent had reported that they had changed the ART drug for some reason, with the major (16.9\%) reason being drug side effect. (Table 3 ). 
Table 3

Reproductive and general health characteristics of ART user's women attending Adama town public health facility, Central Ethipia, $2019(n=396)$

\begin{tabular}{|c|c|c|}
\hline Characteristics of respondent & Frequency (n) & Percentage (\%) \\
\hline \multicolumn{3}{|l|}{ History of ever pregnancy } \\
\hline Yes & 319 & 80.6 \\
\hline No & 77 & 19.4 \\
\hline \multicolumn{3}{|l|}{ Current pregnancy } \\
\hline Yes & 34 & 8.6 \\
\hline No & 362 & 91.4 \\
\hline \multicolumn{3}{|l|}{ Parity (number of children) } \\
\hline 0 & 45 & 14.1 \\
\hline $1-4$ & 241 & 75.3 \\
\hline$\geq 5$ & 34 & 10.6 \\
\hline \multicolumn{3}{|l|}{ Age at sexual debut } \\
\hline$<15$ & 126 & 31.8 \\
\hline$\geq 15$ & 270 & 68.2 \\
\hline \multicolumn{3}{|c|}{ Condom use (on recent sexual act) } \\
\hline Yes & 183 & 46.7 \\
\hline No & 211 & 53.3 \\
\hline \multicolumn{3}{|l|}{ History of current use of FP } \\
\hline Yes & 199 & 68.6 \\
\hline No & 91 & 31.4 \\
\hline \multicolumn{3}{|c|}{ Duration since HIV Diagnosis (yrs) } \\
\hline $1-2$ & 13 & 3.3 \\
\hline $2-5$ & 111 & 28.0 \\
\hline $6-10$ & 122 & 30.8 \\
\hline$>10$ & 150 & 37.9 \\
\hline
\end{tabular}

- Values are presented as a frequency and percentage
- HIV, Human immunodeficiency virus

Page $11 / 27$ 


\begin{tabular}{|c|c|c|}
\hline Characteristics of respondent & Frequency (n) & Percentage (\%) \\
\hline \multicolumn{3}{|l|}{ Aware of partner HIV status } \\
\hline Yes & 342 & 86.4 \\
\hline No & 54 & 13.6 \\
\hline \multicolumn{3}{|l|}{ Sero-status of the partners } \\
\hline Concordant & 264 & 66.7 \\
\hline Discordant & 78 & 19.3 \\
\hline Did not know their partner sero status & 54 & 13.6 \\
\hline \multicolumn{3}{|l|}{ Viral load } \\
\hline Target detectable & 38 & 9.8 \\
\hline Target not detectable & 358 & 90.2 \\
\hline \multicolumn{3}{|c|}{-Values are presented as a frequency and percentage } \\
\hline \multicolumn{3}{|l|}{ - HIV, Human immunodeficiency virus } \\
\hline
\end{tabular}

Summary of women's attitude or opinion to partner violence that is, the circumstance in which they believed it was acceptable/justifiable for a man to hit or physically mistreat her partner were summarized in (Fig. 1).

The prevalence of current intimate partner violence by Women belief or opinion to different gender submissive situation to which they were asked whether agreed or not was summarized under Fig. 2. Accordingly, higher violence was observed among (54\%) women who agreed with the statement of a man should show who the boss is and summarized in. (Fig. 2).

\section{Perceived social support and past history of exposure to non-partner violence}

Level of perceived social support of the respondent was measured by using composite variables of twelve items in a likert scale and history of past exposure to violence was compiled under table (Table 4). 
Table 4

Distribution of perceived social support level and past exposure history to nonpartner violence among ART users' women attending Adama town public health facility, central Ethiopia $2019(n=396)$

\begin{tabular}{|lll|}
\hline Characteristics & Frequency (n) & Percentage (\%) \\
\hline Perceived social support level of women & & \\
\hline Low social support & 185 & 46.7 \\
\hline Medium social support & 119 & 30.1 \\
\hline High social support & 92 & 23.2 \\
\hline Exposure to non-partner physical abuse & & \\
\hline Yes & 160 & 40.4 \\
\hline No & 236 & 59.6 \\
\hline Exposure to non-partner sexual abuse & & \\
\hline Yes & 80 & 20.2 \\
\hline No & 316 & 79.8 \\
\hline Eposure to family incest (sexual) & & \\
\hline Yes & 46 & 88.4 \\
\hline No & 350 & \\
\hline -Values are presented as frequency and percent & \\
\hline
\end{tabular}

Prevalence of Intimate partner violence and common types of violence experienced by women in the past year and in their lifetime

The prevalence of current and lifetime intimate partner violence (physical or sexual/ both) among ever partnered women were $32.3 \%(95 \% \mathrm{Cl} 27.7 \%, 37.1 \%)$ and $45.5 \%(95 \% \mathrm{Cl} 40.7 \%, 51 \%)$ respectively. Current physical, sexual and emotional violence among interviewed women were found to be 107 (27\%), 90 (22.7\%) and $165(41.7 \%)$ respectively.

Slapping or threw something at her, $89(22.5 \%)$ were the commonest reported physical act of violence followed by pushing/pulling hair $64(16.2 \%)$. In most of the respondents, sexual violence was a result of fear 73 (18.3\%). Insulting or making her feel bad 139 (35.1\%) was the common emotional act reported from emotional violence (Table 5). 
Table 5

Prevalence rate of different form and acts of violence among ART users' women attending Adama town public health facility, central Ethiopia, 2019

\begin{tabular}{|c|c|c|}
\hline Types of violence & $\begin{array}{l}\text { Frequency } \\
(n=396)\end{array}$ & $\begin{array}{l}\text { Percentage } \\
\text { (\%) }\end{array}$ \\
\hline \multicolumn{3}{|l|}{ Physical IPV - at least one act } \\
\hline Slapped or threw something at you & 89 & 22.5 \\
\hline Pushed/shoved/pulled her hair & 64 & 16.2 \\
\hline Hitting that could hurt her & 46 & 11.6 \\
\hline Kicked/ beating her & 45 & 11.4 \\
\hline Choked or burnt you on purpose & 10 & 2.50 \\
\hline Threatened or used a gun/knife & 25 & 6.30 \\
\hline Total physical violence & 107 & 27.0 \\
\hline \multicolumn{3}{|l|}{ Sexual IPV- at least one act } \\
\hline Physically forced you to do sex & 55 & 13.90 \\
\hline Having sex when she didn't want b/c she afraid what he may do & 73 & 18.40 \\
\hline Did force you to do something degrading or humiliating & 13 & 3.30 \\
\hline Total sexual violence & 90 & 22.7 \\
\hline \multicolumn{3}{|l|}{ Emotional IPV - at least one act } \\
\hline Insult or made you feel bad about you & 139 & 35.1 \\
\hline Belittled or humiliating you in front of others & 67 & 16.9 \\
\hline Did things to scare or intimidate you purposely & 70 & 17.7 \\
\hline Threatened to hurt you or someone you care & 50 & 12.6 \\
\hline Total Emotional violence & 165 & 41.7 \\
\hline
\end{tabular}

Most of the time violence that arises from partner was characterized by its overlapping nature. In this study also some form of IPV was overlapped with the other form of IPV. About $15.7 \%$ of women who reported experiencing of physical violence had reported experience of both sexual and emotional violence (Fig. 3).

\section{Factor associated with current intimate partner violence among ART users' women}


On bivariate logistic analysis thirteen variables, i.e. partner's occupation, partner alcohol use, partner multiple sexual relationship, partner fighting history, current use of any form of modern contraceptive, condom use, respondent exposure to physical and sexual non partner violence after 15 years and condition how first sexual intercourse initiated were found to be associated with the outcome of interest. Age at sexual initiation of respondent, partner drug use history, age of respondent and women who agree with wife beating in case a woman refuse sex were significantly associated with the outcome variable.

Multivariable logistic regression analyses revealed that, partner occupation being farmer $[A O R=3.9(1.43$, 10.79)], partner engagement in multiple sexual relationships [AOR $=2.2(1.21,4.06)]$, coerced first sexual intercourse $[A O R=3.06(1.73,5.44)]$, current use of modern contraceptve $[A O R=3.33(1.67,6.62)]$ and women who agreed with justification of wife beating in case when she refused to have sexual intercourse with him $[A O R=2.3(1.29,4.12)]$ were significantly associated with experiencing intimate partner violence. (Table 6) 
Table 6

Factor associated with current intimate partner violence among ART users' women attending Adama town public health facility, central Ethiopia, $2019(\mathrm{~N}=396)$

\begin{tabular}{|c|c|c|c|c|}
\hline \multirow[t]{2}{*}{ Variables } & \multicolumn{2}{|c|}{ Experience of violence } & \multirow[t]{2}{*}{ COR (Cl 95\%) } & \multirow[t]{2}{*}{$\operatorname{AOR}(95 \% \mathrm{Cl})$} \\
\hline & Yes & No & & \\
\hline \multicolumn{5}{|l|}{ Partner occupation } \\
\hline Unemployed & $40(68.0)$ & $68(32.0)$ & $\begin{array}{l}1.30 \\
2.23)\end{array}$ & $\begin{array}{l}1.99(0.97 \\
4.06)\end{array}$ \\
\hline Farmer & $19(41.3)$ & $27(58.7)$ & $\begin{array}{l}1.95(0.97 \\
3.93)^{\star}\end{array}$ & $\begin{array}{l}3.93(1.43 \\
10.79) \star\end{array}$ \\
\hline Merchant & $33(37.1)$ & $56(62.7)$ & $\begin{array}{l}1.63(0.92 \\
2.90)\end{array}$ & $\begin{array}{l}1.81(0.81, \\
4.02)\end{array}$ \\
\hline Government employees & $36(26.5)$ & $100(73.5)$ & 1.00 & 1.00 \\
\hline \multicolumn{5}{|c|}{ Partner engagement in multi sexual relationship } \\
\hline Yes & $80(39.4)$ & $123(60.6)$ & $\begin{array}{l}1.96 \\
3.02)^{\star}\end{array}$ & $\begin{array}{l}2.21(1.21 \\
4.06)^{\star}\end{array}$ \\
\hline No & $48(24.9)$ & $145(75.1)$ & 1.00 & 1.00 \\
\hline \multicolumn{5}{|l|}{ Use of contraceptive (any) } \\
\hline Yes & $66(33.2)$ & $133(66.8)$ & $\begin{array}{l}2.32(1.25 \\
4.30)^{\star}\end{array}$ & $\begin{array}{l}3.33(1.67 \\
6.62)^{\star}\end{array}$ \\
\hline No & $16(17.6)$ & $75(82.4)$ & 1.00 & 1.00 \\
\hline \multicolumn{5}{|c|}{$\begin{array}{l}\text { A woman agreed with wife beating if she refuses to have sex } \\
\text { with her partner }\end{array}$} \\
\hline Agree & $69(40.1)$ & $103(59.9)$ & $\begin{array}{l}1.87(1.22 \\
2.86)^{*}\end{array}$ & $\begin{array}{l}2.31(1.29 \\
4.12)^{\star}\end{array}$ \\
\hline Disagree & $59(26.3)$ & $165(73.7)$ & 1.00 & 1.00 \\
\hline \multicolumn{5}{|c|}{ Condition of 1 st sexual debut } \\
\hline Coerced & $66(43.4)$ & $86(56.6)$ & $\begin{array}{l}2.25(1.46 \\
3.46)^{\star}\end{array}$ & $\begin{array}{l}3.0(1.73 \\
5.44)^{\star}\end{array}$ \\
\hline Consented & $62(25.4)$ & $182(74.6)$ & 1.00 & 1.00 \\
\hline \multicolumn{5}{|c|}{ Partner involvement in Riot } \\
\hline Yes & $61(47.7)$ & $91(34.0)$ & $\begin{array}{l}0.56(0.36 \\
0.86)\end{array}$ & $\begin{array}{l}0.55(0.03 \\
1.02)\end{array}$ \\
\hline No & $67(52.3)$ & $177(66.0)$ & 1.00 & 1.00 \\
\hline
\end{tabular}

*statistically significant at $p<0.05$ with COR: crude odds ratio AOR, adjusted odds ratio 


\begin{tabular}{|c|c|c|c|c|}
\hline \multirow[t]{2}{*}{ Variables } & \multicolumn{2}{|c|}{ Experience of violence } & \multirow[t]{2}{*}{ COR (Cl 95\%) } & \multirow[t]{2}{*}{ AOR $(95 \% \mathrm{Cl})$} \\
\hline & Yes & No & & \\
\hline \multicolumn{5}{|c|}{ Physical violence before age 15} \\
\hline Yes & $58(45.3)$ & 102(38.1) & $\begin{array}{l}1.34(0.88 \\
2.06)\end{array}$ & $\begin{array}{l}1.02 \\
(0.53,1.98)\end{array}$ \\
\hline No & $70(54.7)$ & $166(61.9)$ & 1.00 & 1.00 \\
\hline \multicolumn{5}{|c|}{ Sexual violence before age 15} \\
\hline Yes & $37(28.9)$ & $43(16.0)$ & $\begin{array}{l}2.1(1.28 \\
3.51)\end{array}$ & $\begin{array}{l}1.88(0.89 \\
3.95)\end{array}$ \\
\hline No & $91(71.1)$ & $225(84.0)$ & 1.0 & 1.00 \\
\hline \multicolumn{5}{|c|}{ Did you use condom last time you have sex with your partner } \\
\hline Yes & $53(41.4)$ & $132(49.3)$ & $\begin{array}{l}0.72(0.47 . \\
1.11)\end{array}$ & $\begin{array}{l}0.88(0.48 \\
1.61)\end{array}$ \\
\hline No & $75(58.6)$ & $136(50.7)$ & 1.00 & 1.00 \\
\hline \multicolumn{5}{|c|}{ Respondent age category } \\
\hline Young & $29(22.7)$ & $90(33.6)$ & $\begin{array}{l}0.57(0.35 \\
0.94)\end{array}$ & $\begin{array}{l}0.89(0.46 \\
1.70)\end{array}$ \\
\hline Older & 99(77.3) & $178(66.4)$ & 1.00 & 1.00 \\
\hline \multicolumn{5}{|l|}{ Partner drug use history } \\
\hline Every day & $34(26.6)$ & $92(34.3)$ & $\begin{array}{l}0.72(0.44 \\
1.19)\end{array}$ & $\begin{array}{l}0.61(0.30 \\
1.23)\end{array}$ \\
\hline Once or twice a week & $21(16.4)$ & $35(13.1)$ & $\begin{array}{l}1.18(0.63 \\
2.18)\end{array}$ & $\begin{array}{l}1.17(0.46 \\
2.97)\end{array}$ \\
\hline Once or twice a month & $6(4.7)$ & $9(3.4)$ & $\begin{array}{l}1.31(0.44 \\
3.84)\end{array}$ & $\begin{array}{l}0.87(0.21 \\
3.67)\end{array}$ \\
\hline Never & $67(52.3)$ & $132(49.3)$ & 1.00 & 1.00 \\
\hline \multicolumn{5}{|c|}{ Partner alcohol intake status } \\
\hline Never & $43(27.9 \%)$ & $111(72.1 \%)$ & 1.00 & 1.00 \\
\hline 1 to 2 times a week & $8(25 \%)$ & $24(75.0 \%)$ & $\begin{array}{l}1.6(1.00 \\
2.72)\end{array}$ & $\begin{array}{l}1.26(0.63 \\
2.54)\end{array}$ \\
\hline 1 to 2 times a month & $28(41.8 \%)$ & $39(58.2 \%)$ & $2(1.13,3.86)$ & $\begin{array}{l}0.86(0.32 \\
2.30)\end{array}$ \\
\hline
\end{tabular}




\begin{tabular}{|c|c|c|c|c|}
\hline \multirow[t]{2}{*}{ Variables } & \multicolumn{2}{|c|}{ Experience of violence } & \multirow[t]{2}{*}{ COR (Cl 95\%) } & \multirow[t]{2}{*}{ AOR $(95 \% \mathrm{Cl})$} \\
\hline & Yes & No & & \\
\hline Daily & $49(34.3)$ & $94(65.7 \%)$ & $\begin{array}{l}0.97(0.40 \\
2.35)\end{array}$ & $\begin{array}{l}1.37(0.43 \\
4.35)\end{array}$ \\
\hline
\end{tabular}

\section{Discussion}

The study tried to assess the prevalence of current IPV and factors that predispose ART users' women to violence perpetrated from their current/most recent partner. As IPV, in the context of HIV, is important not just only to the individual affected but also to wider society as it contributes significantly to ongoing HIV transmission, women needs to be free from violence. However, the prevalence of violence in this study was found to be significant as one in three women reports at least two or more forms of violence from their partner.

The prevalence of past-twelve month/current IPV in this study was $32.3 \%$, which is almost comparable to the finding from study in Uganda and Nigeria, in which the prevalence rate was (29.3\%) (31) and (35\%) (32)respectively. However, this finding was much higher than finding of study done in the United Kingdom $14 \%$ (33) and United States of America 26.5\% (34). This variation may be due to the fact of variation in socio-economic status and health service coverage as this country were better in socioeconomic status and other gender related health service coverage. In other direction living in poverty predisposes women to an increased rate of violence which was supported by different findings $(35,36)$. Another possible suggested explanation is that low educational attainment predisposes women to elevated level of violence from their partner. This can be a possible explanation among this woman in which, majority attained low education and did not have a job outside the house. The difference may also be explained by low attention might be given to intervention targeting reduction of violence like screening of women for violence in routine care provision unit which was not started yet in low-income country like Ethiopia.

In this study, the prevalence of lifetime intimate partner violence was found to be (45.5\%), and in line with the previous finding reported in Ethiopia (46\%)(13). However, this finding was found to be lower than the finding that was reported in Kazakhstan 52\% (37)and Togo 63\% (38). The difference may be explained by the difference in the tool used to measure violence, in which the later used revised conflict tactile scale that is validated against their culture where it adds some additional feature (acts of violence) to measure violence, which might be resulted in an increased report.

On the other hand prevalence rate of sexual (22\%) and emotional violence $(41.7 \%)$ in this study was relatively comparable to other previous study done in Ethiopia, in which the prevalence rate was found to $25.1 \%$ and $43.7 \%$ respectively (13). But this finding was higher than the finding of a study conducted in other African country like Uganda $(17.6 \%, 17.2 \%)$ (31)and Osogbo southwest Nigeria (2\%, $21 \%)(39)$. This difference might be explained by the variation in women included in the study where the current study 
involves women above fifteen years, thus having good coverage to adequately elicit violence that occur among women where, the later involves women above eighteen years. In another direction, difference may be explained by socio-economic difference as this country is relatively better in economic status and availability of activity that increase empowerment of women that is responsible to reduce violence among this country.

Beyond assessing the prevalence rate and common form of IPV within these populations, the study pointed out factors that are associated with the experience of IPV. Accordingly, women related factor that is women exposures to first non-consented/forced sexual act were identified as a predicting factor to violence among this population. The finding was consistent with a finding from a study conducted in Togo (38). The reason may be due to the fact that, experiencing first non-consented or forced sexual abuse leads the girl or women to be socialized and tolerate violence as a normal. This can affect their life, leads the women to increased risk of experiencing violence in their later life and even enroll the women to viscous cycle of IPV if that happen in early age of life. In the other direction living with men who use coercive sexual tactics with her partner are more likely to be abusive in their behavior and this may increase women chance of experiencing violence than their counterpart.

The other women related factor were women who had justified attitudes supportive of partner wife beating in case she refused to have sex with their husband were more likely to experience violence from their partner. A similar finding was also evidenced from the previous study conducted in Togo (38) and Ethiopia (13). This was also supported with qualitative finding, where it described women accepting or passively reacting to the violent action of their partner as a normal were highly vulnerable to violence. This may be due to the fact that as women agree with violence supportive idea and practice that reinforce female subordination and tolerance to male violence, the more likely they blame themselves for the assault and the less likely to report the act of violence which may lead them to accept violence as a normal. Similarly, women who justified some reason of husband-wife beating the more likely they live with abusive partners, which may increase their chance of experiencing violence than those who did not justify as they may terminate the relationship $(40,41)$.

In the other direction being users of any form of contraceptive to delay/prevent pregnancy was found to increase women chance of abuse by about three times from their partner. The finding was in line with other study conducted in Kenya (42)and Zambia (43), where women tried to negotiate contraceptive use were at increased risk of violence. This may be due to the disagreement between partners, that may arise from a difference in fertility desire in which male partner enforce her to be pregnant which were also evidenced in qualitative finding where the women reported physical or emotional abuse following partner awareness of contraceptive use. Another suggestion for the finding might be low awareness related to contraceptive use among male partner which may be explained by their level of education where mainly low educated, indicating knowledge about the contraceptive method is an issue. This might indicate requirement for strong attention to couple oriented reproductive health counseling service for a partner at the health facility. 
In addition to the above factor, the finding of the study also indicated that women whose partner engaged in multiple sexual relationships were at increased rates of violence. The finding was also evidence from a qualitative study, where asking male partner infidelity was found to be a predisposing factor for women to experience violence from their partner. This finding was in line with the finding reported from other study conducted in Togo (38), Kazakhstan (37) and Osogbo southwest Nigeria (44). This may be explained by the fact that some community gives men to have more right, power over women in sexual relationship and even acknowledge multiple sexual relationships outside the marriage. In the other way, women who believe that their husbands have an extra sexual partner may react violently toward a man out of jealousy and men may use violence in response to their partner's accusation of infidelity, all of which leads women to increased violence $(38,45)$.

Among socio-demographic factors, types of husband occupation were identified as a determinant of violence in this study. In the case, those women whose partner was farmers are more likely to experience violence as compared to women whose partner were government employee. This finding was consistent with the finding of a study conducted in Osogbo Nigeria (39). This result may be true, recognizing the difference in the level of education attained and level of access to information on gender equality as most commonly farmer attain lower education and low access rate to information regarding the issue in which both increase chance of involving in abusive behavior

\section{Limitation of the study}

There are some limitations that must be considered when interpreting the results: There might be recalled bias because some information was based on past information (asked retrospectively) and may result in inadequate information. To minimize this, possible effort has been done that women had allowed sufficient time for adequate recall and also provided with multi-option questionnaires. The other limitation may be some variables like age at sex initiation, number of partner and question used to illicit sexual violence from a woman were sensitive in their nature and may result in less disclosure or underreporting due to the social and cultural barrier to disclose her own/her partner issue to another person. To reduce this limitation, a possible effort has been made, that standard world health organization questionnaires in IPV study and well trained female data collectors were used so as to increase disclosure of information. In addition, careful attention were used in the wording of question in each section of questionnaires by forewarning the sensitive nature the question and by assuring that the information should be kept secret. Another limitation is that information on partner is obtained from respondents and this may result in less reliable information.

\section{Conclusion}

In generally, the study found that intimate partner violence among ART user's women in the study area were, a significant public health problem, as much of the women are suffered from high proportion and overlapping form of violence. Around one in three women experienced at least two or more forms of violence from their most recent/current partner in the past twelve months. 
Individual level factors, such as acceptance of violence (a women feeling it is acceptable for a man to hit her wife), exposure to coerced first sexual act, use of any form of contraceptive and partner occupation as a determinant of violence. In addition, relationship factor (male having multi-partnership) was also among the factor that is identified as predisposing factors. This elevated level of IPV among this vulnerable group of women requires combined effort of addressing risky behavior practiced among male partner and challenging women attitude toward violence.

\section{Abbreviations}

USAID: United States Agency for International Development; UNICEF: United Nations Children's Fund, MOE: Ministry of Education; WHO: World Health Organization; SEA: Self -efficacy Assessment; SPSS: Statistical Package of Social Science; Cl: Confidence interval; COR: Crude odds ratio, AOR: Adjusted odds ratio, AAU: Addis Ababa University; MWU: Madda Walabu University

\section{Declarations}

\section{Acknowledgments}

I would like to thank Adama town health office and Adama medical college for their support by providing me information relevant to conduct this research. Finally, I would like to show my gratitude to study participant, data collector and supervisor for their cooperation in providing me their information and facilitating the study process that resulted in the accomplishment of the study.

\section{Authors' contributions}

All authors made substantial contributions to conception and design, acquisition of data, or analysis and interpretation of data; took part in drafting the article or revising it critically for important intellectual content; agreed on the journal to which the article will be submitted; gave final approval of the version to be published; and agree to be accountable for all aspects of the work.

\section{Funding}

Jimma University

\section{Availability of data and materials:}

The data set analyzed during the current study will be available from the corresponding author on reasonable request.

\section{Ethical consideration}


Ethical clearance was obtained from Jimma University, Institute of health, Faculty of Public Health and medical sciences Ethical review committee. Support letter was obtained from the regional health office to Zonal Health office and from the zonal health office to district health office. Informed verbal consent was obtained from respondent to confirm willingness for participation after explaining the objective of the study. The respondent was notified that they have the right to refuse or terminate at any point of the interview. The information provided by the respondents was kept confidential and separate room was used for conducting interviews.

\section{Consent for publication}

Not applicable.

\section{Competing interests}

The authors declare that they have no competing interests.

\section{References}

1. United Nation the General assembly. Declaration on the Elimination of Violence against Women Proclaimed by General Assembly resolution 1993.

2. Breiding MJ, Basile KC, Smith SG, Black MC, Mahendra R. Intimate Partner Violence Surveillance: Uniform Definitions and Recommended Data Elements. Version 2. 2015;VERSION 2.:164.

3. World Health Organization. Understanding and addressing violence against women: Intimate partner violence. world health organization [Internet]. 2012. Available from: http://www.who.int/iris/handle/10665/77432.

4. Stöckl H, March L, Garcia-Moreno. Intimate partner violence among adolescents and young women: Prevalence and associated factors in nine countries: BMC Public Health. 2014;14(1).

5. The Global Coalition on Women and AIDS. (2011): Issue Brief: Stopping violence against women and girls for effective HIV responses [pdf].

6. Campbella JC, Batya ML, Ghandourb RM, Stockmanc JK, Franciscod L, Johns J. W. The intersection of intimate partner violence against women and HIV/AIDS: a review. Int J Inj Contr Saf Promot. 2012;15(4):221-31.

7. Santana MC, Raj A, Decker MR, Marche A, La, Silverman JG. Masculine Gender Roles Associated with Increased Sexual Risk and Intimate Partner Violence Perpetration among Young Adult Men. 2006;83(4):575-85.

8. UNAIDS. UNAIDS Joint Report on Women and girls and HIV. Geneva: 2018.

9. Vetter J, Abuse. HIV status and health-related quality of life among a sample of HIV positive and HIV negative low income women Karen. J Hist Biol. 2006;39(1):89-123. 
10. Chakraborty H, Patted S, Gan A, Islam F, Revankar A. Determinants of Intimate Partner Violence Among HIV-Positive and HIV-Negative Women in India. 2016.

11. Word Health Organization. Global and regional estimates of violence against women: prevalence and health effects of intimate partner violence and non-partner sexual violence: world health organization; Geneva; 2013.

12. UNAIDS. UNAIDS global and regional summary of AIDS epidemic. Geneva: UNAIDS Joint United Nations Programme on HIV/AID; 2018.

13. Deribe L. Determinants of Intimate Partner Violence among HIV Positive Women Attending ART Clinic in Fitche Hospital, Central Ethiopia : Cross Sectional Study. Journal of Pharm Altern Medicine. 2016;13:19-27.

14. International community of women living with HIV(2015). A call to action on women, HIV and Violence. North America: 2015.

15. Iliyasu Z, Abubakar IS, Babashani M. and HSG. Domestic Violence among Women Living with HIV / AIDS in Kano. African Journal of Reproductive Health. 2011;15:41-50.

16. Wyatt GE, Hamilton AB, Myers HF, Jodie B, Ullman D, Chin, Lekeisha A. Sumner, et al. Violence Prevention among HIV-Positive Women with Histories of Violence: Healing Women in Their Communities. Women's Health Issues J. 2011;21(6):255-60.

17. Espino SR, Fletcher J, Gonzalez M, Precht A, Xavier J. and M-SS. Violence Screening and Viral Load Suppression. AIDS patient care STD. 2015;29:36-41.

18. Blackstock OJ, Blank AE, Fletcher J. Considering Care-Seeking Behaviors Reveals Important Differences Among HIV-Positive Women Not Engaged in Care: AIDS patient care and STDs ·. 2015;18.

19. Trimble DD. Intimate Partner Violence and Antiretroviral Adherence Among Women Receiving Care in an Urban Southeastern Texas HIV Clinic. J Assoc Nurses AIDS Care. 2013;24(4):331-40.

20. Siemieniuk RAC, Krentz HB, Gill MJ. Intimate partner violence and HIV: A review Intimate Partner Violence and HIV : A Review. 2013.

21. Hampanda K. Intimate partner violence against HIV-positive women is associated with SubOptimal infant feeding practices in Lusaka, Zambia. Matern Child Health J. 2016;20(12):1-19.

22. Hatcher AM, Smout EM, Turan JM, Christofides N, Stckl H. Intimate partner violence and engagement in HIV care and treatment among women: A systematic review and meta-analysis. 2015;29:36.

23. Weber K, Cole A, Anastos K. and SR. Impact of Lifetime Trauma, Abuse and Violence on Women Living with HIV (WLHIV). 2015.

24. UN General Assembly. United Nations Political Declaration on Ending AIDS sets world on the FastTrack to end the epidemic by 2030. 2016.

25. Durevall D, Lindskog A. Intimate Partner Violence and HIV Infection in sub-Saharan Africa. WORLD Dev [Internet]. 2015;72:27-42. Available from: http://dx.doi.org/10.1016/j.worlddev.2015.02.012. 
26. Li Y, Marshall CM, Rees HC, Nunez A, Ezeanolue EE, Ehiri JE. Intimate partner violence and HIV infection among women: a systematic review and meta-analysis. 2014.

27. Federal HIV/AIDS, Prevention. and Control Office. Strategic Plan II For Intensifying Multisectoral HIV and AIDS Response in Ethiopia. 2014.

28. Heise AL, Hossain M. Measuring intimate partner violence. 2017;(July):1-8.

29. Zimet GD, Dahlem NW, Zimet S, et al. Multidimensional Scale of Perceived Social Support. J Personal Assess. 2015;52:1988.

30. Utility C, Properties P. AUDIT-C, Questionnaire. 2003;163(April).

31. Osinde MO, Kaye DK, Kakaire O. Intimate partner violence among women with HIV infection in rural Uganda: critical implications for policy and practice. BMC Women Health. 2011;7.

32. Ezebuka MO, Erekaha S, Dairo M. Correlates of intimate partner violence among HIV-positive women in southwest Nigeria. Lancet Global Health. 2013;3:23.

33. Dhairyawan R, Tariq S, Scourse R, Coyne K. Intimate partner violence in women living with HIV attending an inner city clinic in the UK: prevalence and associated factors. HIV Medicine. 2013;30310.

34. Anderson JC, Campbell JC, Glass NE, Michele R, Perrin N, Farley J, et al. Impact of intimate partner violence on clinic attendance, viral suppression and CD4 cell count of women living with HIV in an urban clinic setting CD4 cell count of women living with HIV in an urban clinic setting. 2018;121.

35. Khalifeh H, Hargreaves J, Howard LM, Birdthistle I. Intimate Partner Violence and Socioeconomic Deprivation in England. Am J Public Health. 2013;103(3):462-72.

36. Udoyen G. Socio-economic factors and intimate partner violence in selected states of the niger delta, region of Nigeria. Int J Adv Acad Res. 2017;3(3):58-73.

37. El-bassel N, Primbetova S, Terlikbayeva A. Gender-Based Violence Among HIV-Positive Women in Kazakhstan: Prevalence, Types, and Associated Risk and Protective Factors. J sagepub. 2018;24(13):1-21.

38. Patassi A, Kariyiare B, Burgos-Soto J, Encrenaz G, Lawson-evi, Annette K, et al. Intimate partner sexual and physical violence among women in Togo, West Africa: Prevalence, associated factors, and the specific role of HIV infection. Global Health Action. 2014;1.

39. Olowookere SA, Adeleke NA, Fawole OI, Adekanle DA, Abioye-kuteyi EA. Patterns and Correlates of Intimate Partner Violence to Women Living With HIV / AIDS in Osogbo, Southwest Nigeria. 2015;21(11).

40. Association UNW. Ending Violence against Women and Girls Programming Essentials III. 2013; Available from: http://www.endvawnow.org/uploads/modules/pdf/1372349234.

41. Flood M, Pease B. Factors Influencing Attitudes to Violence Against Women. Vol. 10, Trauma, violence \& abuse. 2009. 125-142 p.

42. Stewart FHTJ. Prevention of pregnancy resulting from rape: a neglected preventive health measure. Am J Prev Med. 2000;200AD;74(1):52-5. 
43. Murray LK, Aldrovandi M, Bolton PA, et al. violence and Abuse Among HIV-Infected Women and Their Children in Zambia. J Nerv Ment Dis. 2010;194(8):610-5.

44. Adekanle DA, Adeleke NA, ljadunola MY, et al. Sexual experiences of married HIV positive women in Osogbo, southwest Nigeria : role of inappropriate status disclosure. BMC Womens Health. 2015;4-9.

45. Halim N, Steven E, Reich N, Badi L, Messersmith L. Variability and validity of intimate partner violence reporting by couples in Tanzania. PLoS One. 2018;1-18.

\section{Figures}

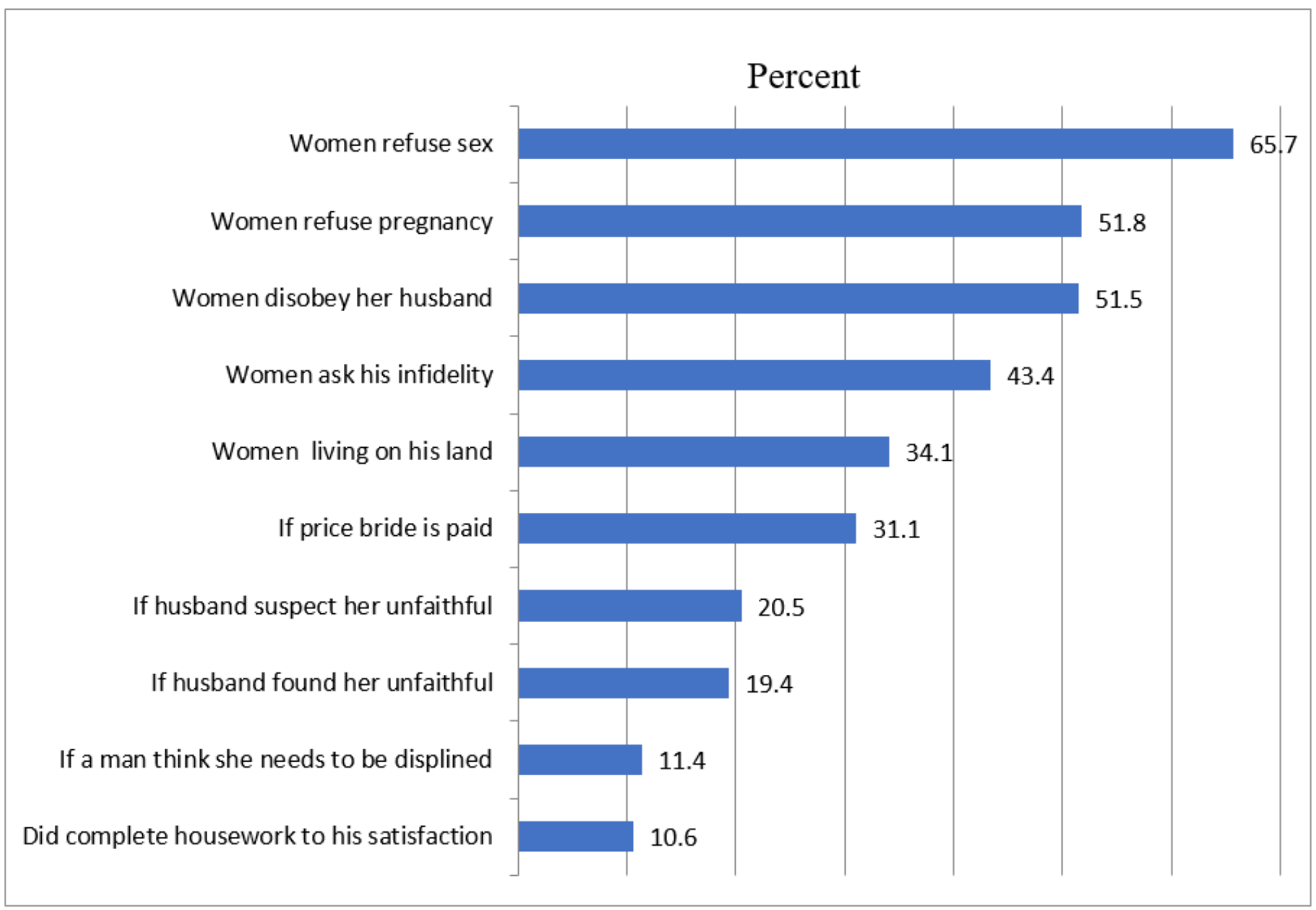

\section{Figure 1}

Distribution of justified reason for wife beating among ART users' women attending Adama town public health facility, Central Ethiopia, 2019. 


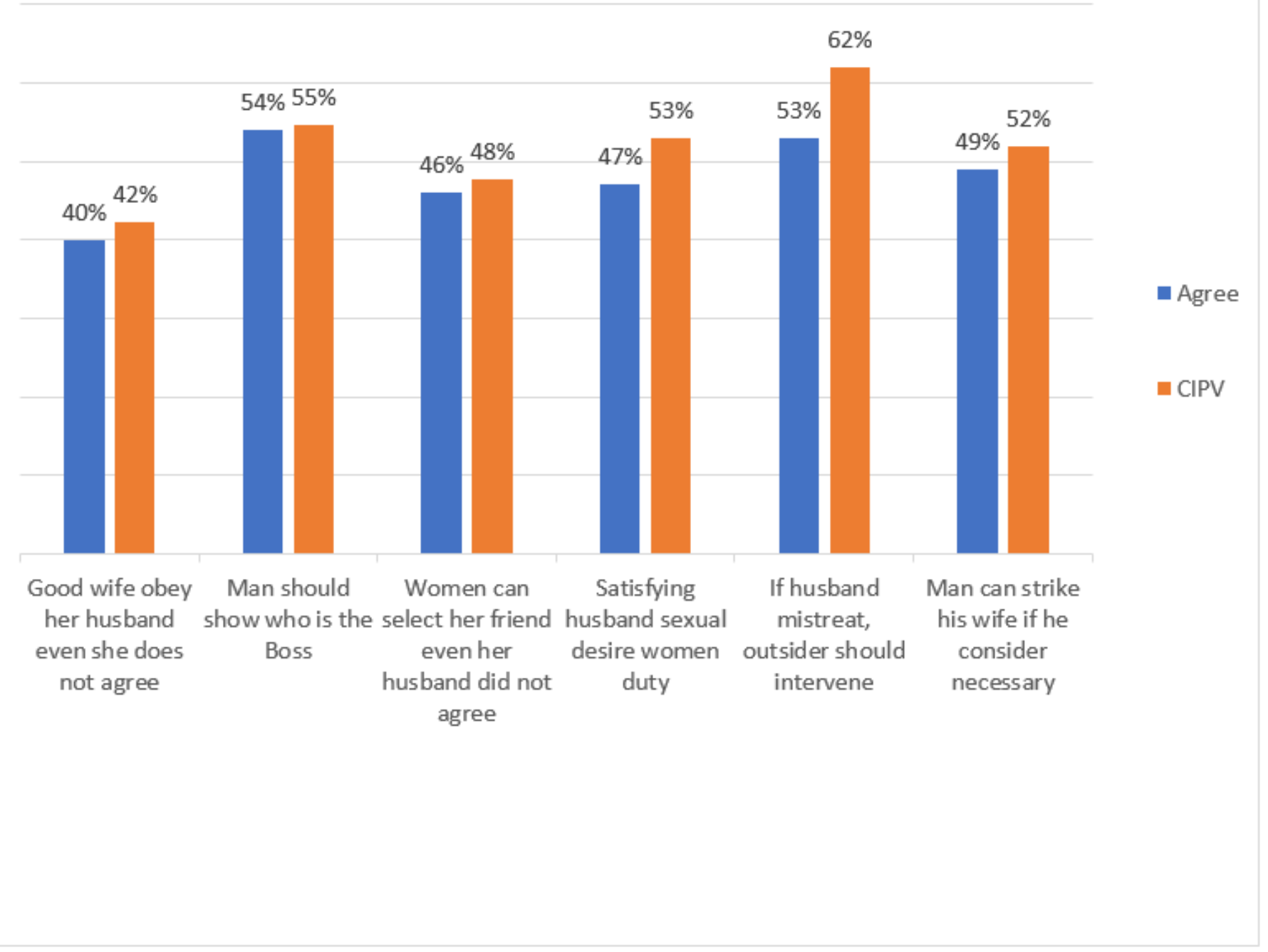

Figure 2

Percentage of women agreed to different gender submissive situation and prevalence of current IPV (CIPV) among ART users' women attending Adama town public health facility, Central Ethiopia, 2019. 


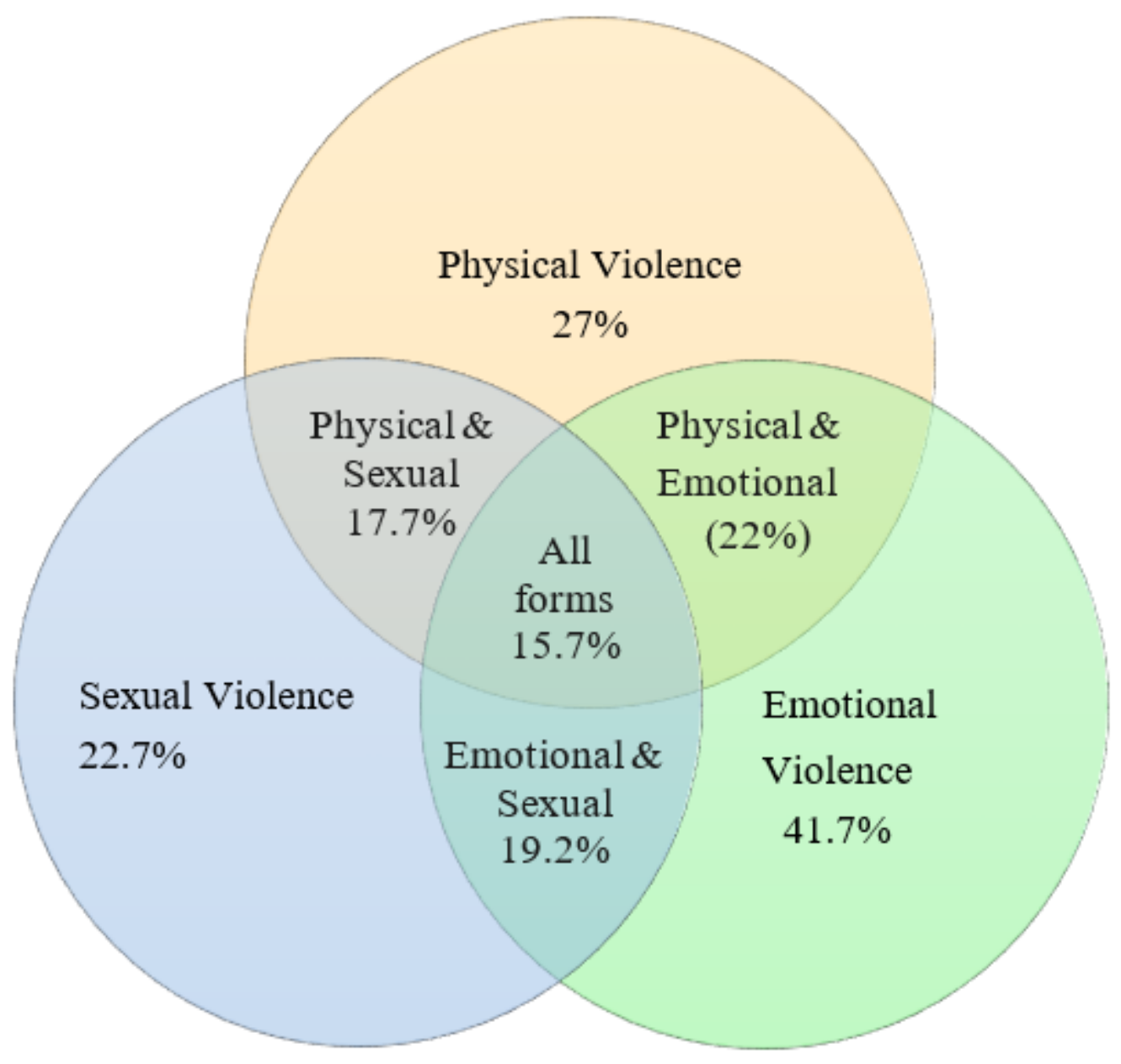

Figure 3

Prevalence rate of overlapped form of violence among respondent attending chronic care unit of Adama town public health facility, Central Ethiopia, 2019.

\section{Supplementary Files}

This is a list of supplementary files associated with this preprint. Click to download.

- STROBEcrosssectionalchecklistIPV.docx 